\title{
EIGHT CRIME FACTOR MODEL FOR YOUTHS IN MEXICAN VIOLENCE CONTEXTS
}

\author{
Sarah-Margarita CHAVEZ-VALDEZ, Oscar Armando ESPARZA Del VILLAR, \\ Leticia RIOSVELASCO MORENO, Dennis RELOJO-HOWELL \\ $\mathrm{Y} \Delta \mathrm{K}$ 159.9.072.433
}

\author{
Сара-Маргаріта Чавес-Вамьдес, Оскар Армандо Еспарза Аель Вімлар, \\ Иетісія Ріосвеласко Морено, Аенніс Релоджо-Ховел \\ ВОСЬМИФАКТОРНА МОДЕЛЬ ЗЛОЧИННОСТІ МОЛОДІ \\ В КОНТЕКСТІ НАСИЛЬСТВА В МЕКСИЦІ
}

\begin{abstract}
The impact of youth violent interactions promoted by: collective fear, and individual coping strategies: youth coping mechanisms, posttraumatic stress traits, measured individually but considered at a collective level and identified as PTSD traits in a community, and social vulnerability as predictors of multifactorial high violence social contexts, are the main psychological mechanisms that Diagnostic on Vulnerability Effectiveness model (DOVE-8) consider as multifactorial factors underpinning cycles of violence, the priority for this diagnostic model examine abovementioned constructs and their association in youth's efficacy, as a collective outcome, DOVE-8 analysis model states that teenagers dealing with specific or widespread fear in violent scenarios, develop certain coping strategies, that furthermore strengthen collective fear. Gradually, an impact on life quality is established, promoting unhealthier mental states and poor social relationships, that consolidate a collective inefficacy, in addition, particular associations were found between high impact crimes and above cited main constructs, that provide a research tool to provide insight into: main fears, coping mechanisms and youth outcomes translated into social ineffectiveness such as: low cohesion, tolerance, participation and respect to law and social norms.

Youth cope can be explained by cognitive and physical strategies. Several traits of posttraumatic stress can promote physiological arousal, followed by emotional or affective coping at violent stimuli or criminal events and, all abovementioned become predictors of crime fear, also known as social anxiety, especially in youth communities with high socio economic and cultural vulnerability. Confronting cognitively a context of violence triggers a rise on risk perception, basically, in privileged- low vulnerability groups with crucial health implications, unnecessary high expenses to cope with crime expectancies in private security at a household level, and stressful fearful coping strategies such as: information distortion, discriminatory processes, low social cohesion, fear based reactions to confront crime, a factor that seen at a glance, might diminish criminal widespread or emotional fear, undoubtedly, this fear type was not found in high vulnerability groups under study. Risk perception was a specific fear commonly found in youth groups with low vulnerability. Both diverse type of fears: specific (risk perception) and widespread fear (social anxiety/crime fear), gather together in a heterogeneous youth community, diminishing collective effectiveness: promoting poor cohesion, low tolerance, discrimination processes, lower levels of social agency, recurrent violent cycles arousals in the community, among other consequences.
\end{abstract}

Key words: collective effectiveness, collective fear, coping styles, posttraumatic stress, youth.

\footnotetext{
Copyright @ CHAVEZ-VALDEZ Sarah-Margarita, ESPARZA Del VILLAR Oscar Armando, MORENO Leticia Riosvelasco, Mexico; RELOJO-HOWELL Dennis, United Kingdom (ЧАВЕС-ВАЛЬДЕС Сара-Маріаріта, ЕСПАРЗА ДеЛЬ ВІЛЛАР Оскар Армандо, РІОСВЕЛАСКО МОРЕНО Летісія, Мексика; РЕЛОДЖО-ХОВЕЛ Денніс, Велика Британія), 2019.
} 


\section{INTRODUCTION}

Social collectives experience events that develop lasting effects of trauma. Unresolved trauma can lead to serious physical and cognitive dysfunctions. Not all effects of collective trauma are included in the complete symptom diagnosis of PTSD. The American Psychiatric Association (2013) DSM-5 classifies PTSD as a traumatic stress-related disorder in their fifth edition. A disorder historically related to war veteran symptoms with particular responses that involve fear and helplessness, as a main characteristic the suffering is persistent and experienced as recurrent dreams, intrusive data recollection and mental repetition, including images, thoughts, or perceptions, including: hallucinations, exaggerated startle response and flashback episodes with feelings of detachment from others and sense of foreshortened future that affect a normal lifespan, high levels of aggression against self and others, social anxiety, and fear, acute depression, personality disorders, dissociation, obsessive compulsive repetition and hyper vigilance of traumatic scenarios, we can refer that there is a prevalence of posttraumatic stress traits in threatened collectives.

The recollection of emotional strategies under trauma acquired through recurrent exposition includes the amygdala and hippocampal memories, among others. Episodic memories influence our reactions, by hyper modulating the amygdala produce progressive devastating effects on the organism and continued environmental challenges, perceived autonomically as threats, an inescapably stressful event that overwhelms individual and collective coping mechanisms and affects identity and future personality in infants and adolescents (Kim, Pellman \& Kim, 2015). Continued emotional arousal strongly affects the formation of long-term explicit memory, hyperactivity of the amygdala affects the hippocampus and its capacity to locate one's place in space and time. As a result, emotional memories can be established without conscious evaluation of incoming information, affecting emotional responses and sensory impressions through the life span (Roozendaal \& McGaugh, 2011).

We understand social fear, as a core construct for scientific study in violent scenarios, a synonym of social anxiety when faced with the possibility of being a crime victim, thus, it is possible to identify two elements on social fear: on the one hand, the emotion of fear, and on the other, the perceived possibility of being a victim (Ruiz, 2007). Faced with fear of crime also known as 'emotional fear' and it is more likely a social anxiety mode in threatened collectives. Young collectives develop coping strategies that sharpen or perpetuate them, which happens indirectly as risk perception increases, considered as an individual protective factor that has shown to diminish crime fear or social anxiety in healthy communities; however, in unhealthy communities, at a midterm, this perception affects life quality, these communities report several posttraumatic stress traits, different anxiety disorders, perception of uncertainty, among other, with effects in collective inefficiency.

Insecurity has filled the void left by ineffective social welfare policies and socially intended to be solved by police security, which positions crime as a crucial issue in the interpretation of youth's reality (Fonseca \& Sandoval, 2005). According to Chomsky (2002), hegemonic social class instrumentalise the fear of criminality provoked by the media to favour their interests.

It is an indisputable fact that social security promotes full development for citizens; without it, the perception of uncertainty and fear tends to 'normalise', which leads to low tolerance, high levels of victimisation, mistrust and attrition in social relations, poor social cohesion, high costs on private security, vulnerability, impotence, thus promoting low levels of collective effectiveness.

As a result, the present study aimed to carry out a general analysis of social fear in two northern cities in the state of Chihuahua (Mexico): the state capital, Chihuahua, and the city of Juarez, a border city with high migration. Both cities have suffered considerable contextual violence, and young people were seriously affected, this required an assessment and analysis of the social networks, factors associated with the behaviour of victims and perpetrators, health, social welfare and the effects on collective effectiveness.

\section{METHOD \\ Participants}

A total of 1193 young adolescents were enrolled: 644 men and 549 women, aged 17 to 21, with a mean age of $19-22(S D=1.11)$, from 52 high schools and university centres of the above cities, $32 \%$ of which were private and the rest public.

Regarding their employment status, only 224 of them worked, who on average had 2-7 years in temporary places, with an average monthly 
income of USD \$121.62, from 64 different urban areas in the city of Chihuahua and 70 in the city of Juarez, resulting in a total of sample was composed by various socio-economic strata: $7 \%$ were high, $21 \%$ medium-high, $23 \%$ medium, $21 \%$ medium-low, 36\% low socio-economical level. Sampling was by conglomerates and the selection of universities was random. Measures were taken over eleven months and participants signed an informed consent prior to the scalers application.

\section{Sample size}

Sample size was estimated using Cohen's (1992) statistical power analysis to detect significant effects of magnitude, based on the results of the pilot studies in Chihuahua (204 participants) and Juarez city (232) and the average range of correlations ( $r$ ) obtained in the main and secondary variables of these studies, ranged from 23 to 35 . In this sense, it was seen that a considerably larger sample was required in order to reduce the confidence interval of the estimate to a range acceptable for the purpose, failure to do so, may lead to the risk of performing the study with an insufficient number of cases, as well as to commit a type II error. That is to say, not to detect a significant correlation between the variables if it applies, because when the statistical power increases, the possibilities of statistical error decrease. Cohen (1992) suggests that the coefficient ( $r$ ) of correlation is itself an indicator of magnitude, of statistical power.

\section{Instruments}

The scales that were used for this study were answered in Likert type scale, which allowed an efficient and reliable measure of sample attitudes, and a complete acknowledge and a compliance degree of the respondent. Thus, we selected the measuring instruments based on the current requirements on collective factor analysis, psychometric qualities and also based on the applicability on youthrs field.

The fact that the instruments met with adaptations, allowed the psychometric qualities of the items to be retained. In addition, in order to corroborate its applicability, a pilot study was carried out in each city, with the intention of adapting to the lexicon and the cultural context in the final sample. The instruments applied, as well as the subjects that were sampled in the research, were considered as key elements to find the relation of theory with practice, as suggested by Gomez (2006). That is, to consolidate the transformation of the conceptual definition into an operational and empirical definition of the data.

The following instruments were used: widespread fear scale, urban coping strategies scale, specific or concrete fear scale, collective efficacy scale and collective posttraumatic traits scale (PTSD).

\section{Widespread Fear Scale}

In the area of criminology, it is often common to distinguish between fear of crime, which is defined as a diffuse widespread, an emotional fear, and on the other hand, the perception of risk of being victimized, also known as "concrete fear", a specific or cognitive fear (Keane, 1995). It is composed of seven items with options of 0 $=$ nothing, $3=\mathrm{a}$ lot, and measures the fear in its emotional component, that is, the fear of crime in the context and the feelings it disseminates, as well as others economic and social fears. In previous studies, an acceptable internal consistency of 0.80 was reached.

It consists of several items about the fear of walking near the house at night, the fear of being a crime victim at home, as well as three items about being afraid of the neighbourhood or city. In the present study, a Cronbach alpha coefficient of 0.95 was obtained.

\section{Urban Coping Strategies Scale}

In order to have a measurement of coping strategies, the following strategic components were considered: affective, physiological, cognitive and behavioural. In this study we chose to use the aforementioned scale, developed by Vuanello (2006), a scale specifically developed to apply in youth groups from violent contexts. It consists of the following four factors:

- Factors 1 and 2: Affective and physiological coping. These factors are characterised by reactions that indicate certain affective elements, such as worry, fear and feelings of insecurity that followed by high autonomic activity and organic repercussions of a stressful response, such as: digestive discomfort, body tension, increased heart rate. The items on the emotional component of the scale are: 'I feel insecure', 'I feel afraid' and 'I worry easily'; in the case of the physiological component, the items are 'I have stomach discomfort', 'My heart rate is accelerating' and 'I have a lot of tension within'.

- Factor 3: Cognitive coping. It brings together two cognitive variables with options to referred thinking about personal capacities to 
increment security due to the concern of experiencing past direct or indirect victimization, reinforcing the anticipation of negative consequences that can be generated by thinking about the crime, or the cognitive or behavioural avoidance of that aggression. This factor also brings together the remaining cognitive variables, which refer to 'think about something else', or 'ignore the difficulties of a dangerous situation or a criminal experience'. The clusters of items that measure this factor are: 'Ignore the problem', 'Think about something else', 'Anticipate the negative things that can happen to me" and "Think about my abilities to solve those situations'.

- Factor 4: Behavioural coping. This factor is defined by the motor type responses, where the highest saturations are the search for social support and trust in the police or institutional protection. Items for behavioural promotion factor are as follows: 'I try to avoid that situation', 'I pray and hope that God will help me', 'I Increase my security measures', 'Seek help from others' and 'Trust the police'. Tobal and Cano (2002) have designed this tool based on the latest version of the Inventory of Situations and Anxiety Answers (ISRA). Situations and responses have been created for the urban insecurity construct. In the reliability analysis using Cronbach's alpha coefficient, the scale obtained a Cronbach alpha of .92 by Vuanello (2006), In San Luis, Argentina. Values shown in Table 1 were found in this study.

Specific fear (perceived risk) Scale

Table 1

Descriptive statistics of CIU Urban Strategies Scale and reliability of principal factors $(N=1193)$

\begin{tabular}{|c|c|c|c|c|}
\hline Scale & A & Item & M & S.D. \\
\hline $\begin{array}{c}\text { Affective } \\
\text { subscale }\end{array}$ & 0.96 & 3 & 1.89 & 0.73 \\
\hline $\begin{array}{c}\text { Cognitive } \\
\text { subscale }\end{array}$ & 0.94 & 4 & 1.87 & 0.56 \\
\hline $\begin{array}{c}\text { Physiological } \\
\text { subscale }\end{array}$ & 0.95 & 3 & 1.88 & 0.78 \\
\hline $\begin{array}{c}\text { Behavioral } \\
\text { subscale }\end{array}$ & 0.93 & 5 & 1.73 & 0.62 \\
\hline
\end{tabular}

This instrument is a Likert scale that includes frequent international crimes, and measure specific fears, such as: violent theft, persecution, extortion, robbery, disappearing, kidnapping, sexual assault, violent death of acquaintances, homicide. It is composed of seventeen items that consists of asking each subject, if he/she considers: unlikely (1), probable (2) or very likely (3) to happen to a relative or an acquaintance any of the 17 offenses described in the items in the subsequent 12 months to the implementation of the scale. In addition, this includes the disappearance of an acquaintance, since this is a form of criminal act recurrent in an important way in that country, as a result of the armed conflict, as well as being persecuted by strangers and receiving anonymous calls (Keane, 1995), Cronbach's alpha in this research was .95 .

\section{Collective Efficacy Scale}

This scale consists of seven items with four response options (from $0=$ nothing to $3=$ much). It measures aspects of collective participation, such as: cityrs affection, respect for legal norms of the city and respect for other citizens. The internal consistency index of the scale, in the latest application the Cronbach's alpha was .91. Each component of the "citizenship culture" construct involves various variables and explanatory models. For example, a survey conducted by the Mayor's Office in Bogota in 2005 found that the people surveyed had positive attitudes towards citizenship norms and respect, but less than half complied with those norms; In addition, they attributed more to themselves than to others the intention to conclude agreements in cases of conflict of citizenrs coexistence. This type of results shows a cognitive bias to believe that one's own behaviour is better than that of others, which helps identify that influence in personal attitudinal variables towards voluntary compliance, tax payment or attachment to the city. In the present study, a Cronbach alpha coefficient of .97 was obtained.

PTSD Scale of Collective Traits for Traumatic Events

This is a brief scale consisting of 24 items that, in short, studies traits that support a diagnosis of posttraumatic stress traits (PTSDt) in populations affected by violence. This scale was developed in Colombia to measure collective PTSD in San Joaquin (Santander), a Colombian population that was partially destroyed by a guerrilla attack in 2000 . 
The scale has a good discriminating capacity and adequate levels of sensitivity and specification. The list of symptoms had excellent internal consistency, with a Cronbach alpha coefficient of 0.97 . In the pilot application, the sample reported a coefficient of 0.94 . The collective PTSD traits, found are as follow: anguish-avoidance, experimentation-somatization, negative mood-dissociation, hyper vigilance, and social distancing.

\section{REVIEW OF PILOT STUDIES}

Two pilot studies were carried out: in the first one, a 224 sample with youths from Chihuahua City, Mйxico, the aforementioned scales were applied; in the second, carried out in the city of Juarez, 237 young people were sampled.

In the first pilot, Coping Strategies Scale, obtained a Cronbach alpha coefficient of 83 . The Specific Fear Scale, a scale specialised in measuring risk perception scale obtained a Cronbach's reliability of .96 , which means that the scale was highly reliable. In relation to the widespread fear scale, a coefficient of .92 was reached.

In the second pilot, items required minimum adaptation and the required changes were made to ensure comprehension and feasibility for a final interpretation of the study. In this second pilot study, the coping strategies scale obtained a Cronbach alpha of .91, thus proving to be reliable. These coefficients in the widespread fear scale were .94 and .96 , respectively.

The pilot tests indicated that there is a consistent and exponential growth in the use of private security, there were also results regarding the construct: "social fear" that were relevant in the risk perception in the city of Chihuahua, and fear of crime in the city of Juarez, with different coping strategies in the main cities of the state. In the specific case of the city of Chihuahua, affective coping strategies and cognitive denial processes were found among young people between the ages of 17 and 21, mainly together with a preponderant perception of risk to be victimized. In the city of Juarez, physiological coping strategies and behavioural coping were detected, together with fear of crime, also known as widespread fear (Chavez and Ríos, 2015). Findings continue under study, a presumption that the social fear type that is more representative can be due regional socio economic, educational and cultural differences in the neighbourhood's should be diagnosed for each community, for instance, in this study and in the theory revised we found relevant differences on the groups under study. The model developed categorises the social fear type on each diagnosis clustering the levels of socio cultural and educational vulnerabilities.

\section{Procedure}

Prior to the data collection process, and after obtaining the permission of the authorities of several private and public high schools and universities, sample was collected, also requesting the informed consent of the sample. The data were collected in distinct lectures of each school. Participants were assured about confidentiality of their responses and had the opportunity to ask the applicator in case of doubt. The questionnaires were completed within an average of 45 minutes. For data analysis, SPSS and AMOS program, version 21 was required.

\section{RESULTS}

The structure of the instruments got analysed since the correlations and the theory that gave support to the constructs and explained their interrelation, and thus along with new contributions reported in this particular research served to understand more in depth the way in which they interact, adding new discovering about the phenomenon on diverse vulnerability levels by each collective fear type and the ineffectiveness interpretation of youth communities for a multifactor development of a social fear model on youthrs ineffectiveness in violence contexts, the model also reports results on eight high impact crimes and the aetiology in terms of the variables analysed.

This new model proposal was analysed with the generalised least squares method. The goodness of fit was evaluated with the comparative adjustment index (IFC), the goodness of fit index (GFI), the mean square approximation error (RMSEA), and the normalized adjustment index (NFI), which are the indicators of more widespread use ( $\mathrm{Hu}$ and Bentler, 1999). The model had the following fit indexes: $\div 2(437)=$ $1337.011(\mathrm{p}<.01), \div 2 / \mathrm{gl}=3.06$, CFI $=.96$, NFI $=.94$, and RMSEA $=.03$, good fit. The Kaiser-Meyer-Olkin sphericity test (KMO) was also applied, which was $>.5$, with a score of .892. In the sample, several biological and contextual variables reported traumas of posttraumatic stress studied through the PTSD traits scale.

The level of PTSD traits symptomatology in the youth was related to low blood pressure 


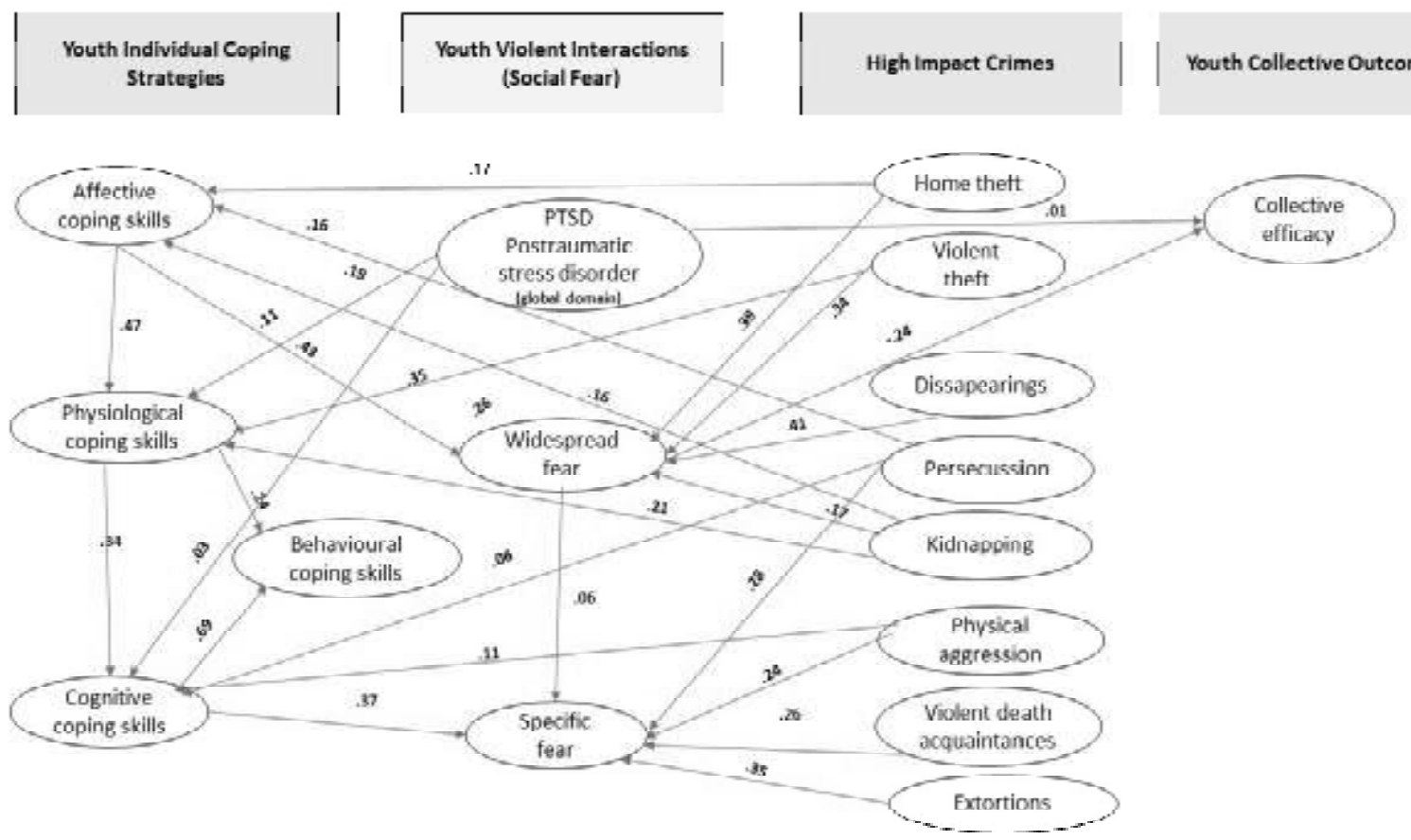

Figure 1

SEM Explanatory Diagram - - Diagnostic On Psycho Social Vulnerability/ Effectiveness DOVE-8 analysis model for collective fear, coping strategies, PTSD, socio economic and cultural vulnerability on youth collective effectiveness in violent contexts (@Chávez, 2018) Note: Simplified Path model. Latent constructs in circles, Regression and covariances are standarized $\left({ }^{* *} \mathbf{P}<.01\right)$

levels; this condition, combined with the relationship with the parent or guardian, was inversely proportional and very significant to the levels of posttraumatic stress in the sample $(\mathrm{r}=-.23[\mathrm{p}<.01])$; the relationship with the mother was significant and inverse to the levels of posttraumatic stress in the youth $(r=-0.05$ $[\mathrm{p}<.05])$. It was found that the level of victimization shown by the participants was not related to the level of posttraumatic stress; however, the sample of 1,193 youngsters presented a level of intermediate high posttraumatic stress.

Regarding the PTSD traits scale, which measures posttraumatic stress traits incidence, the maximum score to obtain a high degree of posttraumatic stress is 4 ; in the present sample we found a general mean for Chihuahua and the city of Juarez of 2.26; In other words, from total posttraumatic stress traits in youth population, $56.5 \%$ of these traits were evidenced in the sample.

\section{MODEL EXPLANATION:}

Figure 1, The Diagnostic on Psycho Social Vulnerability / Effectiveness DOVE-8 analysis model for collective fear, coping strategies,
Table 2

Comparative table of specific, widespread fear, posttraumatic stress traits and collective efficacy in youths

\begin{tabular}{|c|c|c|c|c|}
\hline \multirow{2}{*}{ Factor } & \multicolumn{2}{|c|}{$\begin{array}{c}\text { Chihuahua } \\
\mathrm{N}=621\end{array}$} & \multicolumn{2}{c|}{$\begin{array}{c}\text { Ciudad } \\
\text { Jufrez } \\
\mathrm{N}=572\end{array}$} \\
\cline { 2 - 5 } & Mean & SD & Mean & SD \\
\hline $\begin{array}{c}\text { total widespread } \\
\text { fear }\end{array}$ & 5.50 & 1.31 & 6.51 & 1.15 \\
\hline $\begin{array}{c}\text { total specific } \\
\text { fear }\end{array}$ & 3.80 & 1.54 & 3.76 & 1.40 \\
\hline $\begin{array}{c}\text { collective } \\
\text { efficacy f1 }\end{array}$ & 2.47 & 0.61 & 2.37 & 0.67 \\
\hline $\begin{array}{c}\text { collective } \\
\text { efficacy f2 }\end{array}$ & 2.72 & 0.64 & 2.70 & 0.65 \\
\hline $\begin{array}{c}\text { total collective } \\
\text { efficacy }\end{array}$ & 2.58 & 0.52 & 2.51 & 0.58 \\
\hline total PTSD & 2.25 & 0.62 & 2.28 & 0.53 \\
\hline
\end{tabular}

Note: $\mathrm{SD}=$ Standard widespread fear $\mathrm{fl}=$ fear of crime on a personal level; widespread fear $\mathrm{f} 2$ = fear of crime at a contextual level; total widespread fear $=$ fear of crime total; Personal concrete fear = personal risk perception; Familiar concrete fear $=$ familiar risk perception; collective efficacy $\mathrm{fl}=$ factor 1 (union and trust); collective efficacy factor $2=$ Intervention in the community; total collective efficacy $=$ total collective effectiveness $\mathrm{f} 1+\mathrm{f} 2$; Total PTSD = posttraumatic stress traits in the community (own elaboration). 
Correlations of principal coping strategies, widespread or crime fear,

Table 3 and their association to PTSD traits in the sample

\author{
$\begin{array}{llll}\text { Coping TPSDt } & \text { WF } & \text { Strategies }\end{array}$
}

\author{
Affective \\ Affective \\ Physiological
}

$0.27 * *$

Physio
Behavioral

$0.24^{* * *} \quad-.$.

Cognitive

$0.18^{\text {*4. }}$

Note: ${ }^{*} \mathrm{p}<0.05 ; * * \mathrm{p}<0.01$; CS: Coping strategies; $\mathrm{WF}=$ widespread fear; TCE $=$ total collective effectiveness; TPSDt $=$ total traits of posttraumatic stress in the community; - no correlation between factors analyzed (own elaboration).

PTSD, socio economic and cultural vulnerability on youth collective effectiveness in violent contexts (Chávez, 2018); is an improved version of a first developed model by the author, published by Ensecanza e Investigación Journal, in January 2018, cited as: Chávez, S.M.; Esparza, O.A. y Riosvelasco, L. (2018). Hacia un modelo del impacto del miedo colectivo, estrategias de afrontamiento y estrés postraumático en la eficacia de jóvenes mexicanos. Enseńanza e Investigación en Psicología, 23(1), p.15.

Behavioural coping can be explained by cognitive-physiological components. Affective coping had a .47 factor loading on physiological order responses that youth presents at contextual violence stimuli. Of these, posttraumatic stress of physiological connotation had a factor load of .11; another .16 factor loading of posttraumatic stress traits were affective or emotional biased, predicting a .28 factor loading of widespread or crime fear, which explained a .24 factor loading of collective ineffectiveness in participants. Physiologicalcognitive coping predicted $32 \%$ of the perceived risk level, a specific fear. Fear of crime, a widespread fear associated to affective strategies, thus supporting the theory that states it as an "emotional fear", and the risk perception, also known as concrete or specific fear, was related to cognitive coping strategies, in congruence with the theory that defines it as a "cognitive fear". The widespread fear or diffuse fear was related to the decrement in specific fear in a $14 \%$; fear of crime, decreases collective effectiveness by $24 \%$.
A specific analysis on 8 high impact crimes: Kidnapping presents $24 \%$ association to specific fear and $7 \%$ to widespread fear, a $21 \%$ association to physiological coping skills and a $16 \%$ association to affective coping skills, Persecution presents a correlation of $28 \%$ to specific fear and 19\% were affective coping skills, Physical aggression presented a 24\% association to specific fear and $11 \%$ of association to cognitive coping skills, Extortion, a 35\% association to specific fear, Violent theft was $34 \%$ related to widespread fear and related on a 35\% to physiological coping skills, Home theft, a $39 \%$ association to widespread fear and a $17 \%$ of affective coping skills and a $26 \%$ of behavioural coping skills, Disappearance, were associated in a $41 \%$ to widespread fear and Violent death of acquaintances, $26 \%$ associated to high risk perception, an specific fear.

\section{Coping Strategies and Social Fears}

Both social fears show statistically significant relationships with coping strategies, we can observe in the personal widespread (PWF), total widespread (TWF) and in the (TPTSD) total posttraumatic stress traits, notice that these strategies are basically affective, not necessarily physiological behavioural, the behavioural component, shows a significant, but low correlation with the widespread fear.

Considering the effect size in the relationships found in order of importance, we found what is shown in Table 3. 
Also notice, that the adolescents that manifest widespread fear are mainly coping with affectively or emotional strategies $(r=0.48[p<.01])$ and, on the other hand, adolescents that course with specific fear, also known as: risk perception, cope cognitively $(r=0.37[p<.01])$.

\section{Coping Strategies and Collective Efficacy}

Regarding the relationships between these variables, and the results in the both northern main cities of the state of Chihuahua, there were no statistically significant relationships linking the coping strategies of violence with the first of the two factors that make up the collective efficacy "unity and trust" for our sample, this is crucial because the items that measure unity and trust within social community neighbourhoods refer to the trustiness and willingness to help others, such as, disposition to do something to help others, care about children in need or abandoned.

However, not all was a grey scenario, very significant relationships were found between the four coping strategies and the second factor of collective efficacy, termed "community intervention", in the case of adolescents who cope with cognitive coping strategies, it is the one that showed a bigger effect size of all the strategies, although moderated, $(\mathrm{r}=0.24$ [p $<.01]$ ) it is noticed that cognitive coping is an inherent strategy of the specific fear (risk perception), followed by behavioural coping ( $\mathrm{r}=0.17$ $[\mathrm{p}<.01])$, physiological strategies $(r=0.15$ $[\mathrm{p}<.01])$ and, finally, affective coping $(\mathrm{r}=0.14$ [p <.01]) (see Table 3).

The above correlations indicate a low level of direct community intervention in any of the coping strategies; In short, the participants reached scores that denote low levels of interest to intervene communally in their contexts. It is important to emphasize that those in which the confrontation was primarily cognitive, showed a greater perception of risk, and were those that coincidentally manifested more interest in community intervention; Even so, the level tends to be moderate.

More research is needed on risk perception or specific fear and its implications in violent environments and well scientifically supported strategies that promote collective effectiveness, especially for community intervention; In this way, it is possible to ensure strategies that take into account the positive and protective aspect of vulnerability among young people dealing with violent contexts, which offers a supported analysis on risk perception.
This is essential because a development of a training strategy that includes this specific factor, considering social and subjective as a fundamental element in prevention, involves attending to qualitative issues related to cope with the risks, thus encouraging young people to become individually involved in their own prevention.

Considering risk perception implies some methodological innovation by including the human factor as an approach that unfolds the traditional rationalist point of view in which the agent or person remains as a simple recipient of prevention, to move to an active approach in the achievement of the security, welfare and social health goals, in different instances. According to the results of the present study, this is more feasible in Chihuahua city, Мйxico, in the short term, because in the case of the city of Juarez the risk perception factor did not show significant levels among the participants.

Although the findings indicate that a violent situation generates risk perception in vulnerable groups, a protective factor in the appearance of some kinds of posttraumatic stress traits, these types of groups show that it is only a mirage to control levels on crime fear in youth. The negative impact of this kind of fear on collective efficacy showed in the present research that was out of control, since youngsters' affective thoughts and physiological responses produced a negative effect. Again, those traits of posttraumatic stress were activated with affective thoughts related to the violent situation, so that fear was experienced again, violence inoculated, and somatic. Young people began to use adverse cognitive-behavioural strategies, and as a result they manifested anti-social behaviours, which, together with other social, health and cultural vulnerability factors described in the development of the problem, probed an important denial in life quality, in those who suffer contextual violence. The present development aims to explain how this process is and the slopes that lead to low levels of collective effectiveness.

Analysing diffuse or widespread fear correlated with affective strategies, supported Ruiz's (2007) theory which defines it as an emotional fear, and that of risk perception related to cognitive coping strategies, which also supported the theory that defines it as cognitive fear.

\section{DISCUSSION}

Some points of agreement with current theory, referring to previous studies on the main variables, such as coping strategies, social fear, 
levels of socio economic and cultural vulnerability, collective efficacy and traits of posttraumatic stress in young people, as well as a model was constructed from such analysis.

In the above cities, all coping strategies are moderately related to fear of crime in context, widespread or diffuse fear; however, only affective and physiological strategies show relationships with the two components of fear of crime: personal and contextual. This study found consistency between findings and theory around affective strategies (which were related to fear of crime or diffuse fear) and reinforce the most current theoretical reference which considers it as an emotional fear of the criminal environment and cognitive strategies, related to the perception of risk as a cognitive fear. Both terms described by Keane (1995). The results presented in this study propose a relationship between each of the strategies and diffuse fear, predominantly in the city of Juarez; however, it is important to emphasize that this widespread fear is related to affective and physiological coping strategies, which Vuanello (2006) describes as straightforward related to traits of posttraumatic stress, so that the communityrs health in the city of Juarez is low and certainly compromised. The fact that there were no statistically significant results on risk perception in that city is a factor that must be analysed further to determine clearly its causes; however, it can be asserted for this study that not having an adequate level of risk perception is not at all favourable to communities that are highly exposed to crime, and that the high vulnerability in socio cultural and education level is a relevant factor.

For Moras (2010), behind the pressure to administer more firm punitive measures in violent contexts, underlies a background of beliefs about the extent of insecurity and the excessive growth of crime; such uncertainties have been condensed into the figure of young people and their age characteristics as protagonists of the anxieties and alarm generated by violence and those youngsters act as receivers of the rejections by the same society and communities to which they belong. In the pilot study with youngsters from Chihuahua city, evidence of social fear is revealed, in the modality of specific or concrete fear; that is to say, a high risk to be victimized: This same trend is replicated when analysing the results on the final research. With a higher mean, the risk perception also canrt be related to crime rates and homicides, as it would be logical to find in a city with higher rates of crime, as the case of Juarez city, with a higher criminal rate.

Moras (2010) points out that areas with high homicide rates tend to have low perceptions of insecurity (Chavez and Ríos, 2015; Ruiz, 2007); conversely, a city with a low homicide rate could permeate a high perception of insecurity; despite this, the young people of Chihuahua city showed a greater risk perception of being victimized.

Chavez (2015) points out that when there are high levels of both kinds of social fear, some potential victims resort to group self-protection behaviour, which is a favourable factor for life quality of youths, this would be the case for the city of Chihuahua, who manifested considerable levels of high perception of risk among their young people, who, when recognized as vulnerable, promote such self-care behaviours, thereby significantly reducing their level of exposure and vulnerability in the long term. Although, this protective kind of fear factor, turned out to be higher in the sample of young people with access to greater economic, social and educational resources for a threatening context.

\section{REFERENCES}

1. Chávez, S. (2015). El surgimiento de la victimización colectiva en México. Paper presented in the $11^{\text {th }}$ International Congress of Qualitative Inquiry (ICQI 2015).Chicago, IL: University of Illinois at Urbana-Champaign. Recovered from http://www.icqi.org/QI2015-Final-Program-043015.

2. Chávez, S. y Ríos V., L. (2015). Intervención para el desarrollo socioemocional, la conducta prosocial y la inhibición de la conducta violenta en jóvenes. Memories of the first Regional Conference in Psychology "Advances and challenges on Psychology in Latin America” (pp. 921-922). Bogotá: Colegio Oficial de Psicólogos de Colombia.

3. Chávez, S.M.; Esparza, O.A. y Riosvelasco, L (2018). Hacia un modelo del impacto del miedo colectivo, estrategias de afrontamiento y estrés postraumático en la eficacia de jóvenes mexicanos. Enseñanza e Investigación en Psicología, 23(1), p.15.

4. Chomsky, N. (2002). Propaganda and public opinion. Barcelona: Crítica.

5. Cohen, J. (1992). A power primer. Psychological Bulletin, $112(1), 155-159$.

6. Fonseca, K. y Sandoval, C. (2005). Communication media and citizen insecurity in Costa Rica. San José: Programa de las Naciones Unidas para el Desarrollo.

7. García-Castro, J.D. y Barrantes U., B. (2014). Perception and fear of crime: Articles in Spanish revised 20042014.Reflexiones, 95(1), 87-100.

8. Gómez, M.(2006). Scientific Methodology Research. México: Brujas.

9. Hu, L. y Bentler, P.M. (1999). Cutoff criteria for fit indexes in covariance structure analysis: Conventional criteria versus new alternatives. Structural Equation Modeling, 6(1), 1-55.

10. Keane, C. (1995). Victimization and fear: assessing the 
role of offender and offence. Canadian Journal of Criminology, 37(2), 431-455.

11. Kim, EJ, Pellman, B., y Kim, JJ (2015). Efectos de estrés en el hipocampo: una revisión crítica. Aprendizaje y memoria, 22 (9), 411-416.http://doi.org/10.1101/lm.037291.114

12. Méndez, J., Villar, A., y Becerril, T. (2009). An approach to fear feeling and its impact on the reconfiguration of social spaces. Urbano, 12(19), 79-92.

13. Morás, L. (2010). Tranquilizar y proteger. El miedo ante el asedio de los jóvenes violentos y el abismo de las instituciones. Memories of the IX Jornadas de Investigación de la Facultad de Ciencias Sociales. Montevideo: Universidad de la República, 13-15 de septiembre.

14. Roozendaal, B., \& McGaugh, J. L. (2011). Memory Modulation. Behavioral Neuroscience, 125(6), 797-824. http:/ /doi.org/10.1037/a0026187

15. Ruiz J., I. (2007). Cultura ciudadana, miedo al crimen y victimización: Un análisis de sus interrelaciones desde la perspectiva del tejido social. Acta Colombiana de Psicología, $10,65-74$.

16. Tobal, J.J. y Vindel, A. (2002). Inventario de Situaciones y Respuestas de Ansiedad (ISRA): Manual (5 rev.). Madrid: TEA.

17. Vuanello, R. (2006). Un nuevo instrumento de evaluación psicológica: El Cuestionario de Inseguridad Urbana. Revista Interdisciplinaria, 23(1), 17-45.

\section{АНОТАЦІЯ}

Сара-Мартаріма Чавес-Вальдес, Оскар Армандо Еспарза Дель Віллар, Летісія Ріосвеласко Морено, Денніс Релоджо-Ховел.

Восьмифакторна модель злочинності молоді в контексті насильства в Мексиці.

Вплив насильства серед молоді спричинено колективним страхом. Індивідуальні стратегії копінгу механізми подолання молоддю ознак посттравматичного стресу (ПТСР), що виміряні індивідуально, проте розглядаються на колективному рівні та ідентифікуються як ознаки такого стресу в суспільстві. Соціальна вразливість як передвісник довкільного контексту багатофакторного насильства є основними психологічними механізмами, котрі виявляються Моделлю діагностики ефективності вразливості (DOVE-8) як ті фактори, що узасаднюють цикли насильства. Пріоритетом для цієї діагностичної моделі є вивчення конструкцій та їх асоціацій у здатності молоді ефективно функціонувати як колективне утворення. Модель DOVE-8 стверджує, що підлітки, які працюють зі специфічним або широко розповсюдженим страхом у сценаріях насильства, вдосконалюють певні стратегії допінг-подолання, який ще більше зміцнює колективний страх. Поступово встановлюється вплив останнього на якість життя, що спричинюе нездорові пси- хічні стани та негативні соціальні відносини, які консолідують колективну нездатність ефективно функціонувати. Крім того, були виявлені певні асоціативні зв'язки між значним упливом злочинів і вищезгаданими емпіричними конструкціями, які задіюють дослідницький інструментарій для прояснення перебігу основних страхів. Механізми подолання та молодіжні показники перекладені на соціальну неефективність, зокрема таку як низька згуртованість, толерантність, участь і повага до закону і соціальних норм.

Те, що допомагає молоді справитися з вищезгаданими страхами можна пояснити когнітивними та фізичними стратегіями. Декілька ознак посттравматичного стресу можуть сприяти фізіологічному збудженню, який виникає після емоційного або афективного подолання при насильницьких стимулах чи кримінальних подіях. I все це стає передвісником страху злочину, також відомого як соціальна тривога, особливо серед молодіжних громад з високою соціальноекономічною і культурною вразливістю. Когнітивне зіткнення контексту насильства викликає зростання ризику сприйняття здебільшого у привілейованих 3 низькою вразливістю групах з критичними наслідками для здоров'я. Воднораз доведено, що непотрібні високі витрати для подолання очікуваних злочинів у приватній безпеці на рівні домогосподарств, а також стратегії подолання стресової боротьби, а саме шляхом відбору інформації, унеможливлення розвою процесів дискримінації, підвищення соціальної згуртованості і нейтралізації природної реакції на залякування, що впливає на скоєння злочину, саме цей фактор є першорядним у применшенні кримінального широкомасштабного або суто емоційного страху. Безсумнівно, цей тип страху не був виявлений в обстежуваних групах 3 високою вразливістю. Сприйняття ризику було специфічним страхом, що часто зустрічається у молодіжних групах з низькою вразливістю. Як різноманітні типи страхів - специфічний (сприйняття ризику) і поширений (соціальна тривожність та страх злочину) - поєднуються у гетерогенному молодіжному гурті, зменшуючи колективну ефективність: а) сприяють слабкій згуртованості, б) низькій толерантності, в) процесам дискримінаціі, г) нижчим рівням соціального агентства, д) періодичним збудженням насильницьких циклів у громаді, та ін.

Ключові слова: молодь, колективна ефективність, колективний страх, стилі подолання, посттравматичний стрес.

Рецензенти:

д. психол. н., проф. Болтівець С.І., д. психол. н., проф. Раку I.

Надійшла до редакції 11.05.2019. Підписана до друку 30.05.2019.

Бібліографічний опис для цитування:

Chavez-Valdez S.M., Esparza Del Villar O.A., Riosvelasco Moreno L., Relojo-Howell D. Eight crime factor model for youths in Mexican violence contexts. Психологія i суспільство. 2019. №2. C. 98-107. https://doi.org/10.35774/pis2019.02.098 